\title{
BIOCHEMICAL ASPECTS OF CASSAVA (MANIHOT ESCULENTA CRANTZ) WITH SPECIAL EMPHASIS ON CYANOGENIC GLUCOSIDES - A REVIEW
}

\author{
E.R. JANSZ and D. INOKA ULUWADUGE \\ Department of Biochemistry, Faculty of Medical Sciences, University of Sri \\ Jayewardenepura, Nugegoda.
}

(Received: 11 July 1996; accepted: 07 February 1997)

\begin{abstract}
This review on some biochemical aspects of cassava contains 113 references. It is primarily focussed on the cyanogenic glucosides and glucosidases of cassava covering its biosynthesis, cyanide liberation, the effect of processing and detoxification specially pointing out the different approaches in Africa and South Asia and the acute and chronic toxic effects of cyanide. It also covers the recent literature on photosynthesis and nutritive aspects of cassava.
\end{abstract}

Key words: Cassava, cyanogenic glucosides, linamarase, nutritive value, photosynthesis, processing, toxicity detoxification.

\section{INTRODUCTION}

Manihot utilissima Phol or Manihot esculenta Crantz. is widespread in the tropical world, and commonly known as manioc, cassava, tapioca, mandioca, etc. Its primary attraction is that in its tuberous root, it is the highest yielding starchy staple where yields as high as 50 to 82 metric tons per hectare have been recorded . Further, (i) albeit with lesser yields, it can be grown on marginal soils ${ }^{1,2}$ where an economic yield cannot be obtained from other crops; (ii) it is attacked by few pests other than rodents. The major deterrent to its cultivation is its proven reputation as a $\mathrm{K}^{+}$soil depleter ${ }^{2}$ which is probably due to its high yields.

Factors such as the time of harvest, cultivars and environment ${ }^{3,4}$ affect cyanogenic glucosides and starch contents but being agricultural aspects ${ }^{3,4}$ are not considered in this review.

\section{PHOTOSYNTHESIS}

Prompted probably by the high starch yields, investigations have been undertaken on the mechanism of photosynthesis of cassava. It has been reported ${ }^{5,6}$ that (i) photorespiration in cassava is low; (ii) a high percentage $\mathrm{CO}_{2}$ fixation takes place through the C-4 pathway; (iii) it had a high PEP carboxylase activity although it did not have the characteristic Krantz anatomy of a C-4 plant and (iv) an appreciable amount of carbon assimilation also takes place through the Calvin cycle. However; in a conflicting report Edwards et al. ${ }^{7}$ state that several 
key C-4 enzymes in cassava are present only in low concentrations and the $\mathrm{CO}_{2}$ compensation points of cassava ranged from 55 to $62 \mu \mathrm{l} / /$ which is typical for $\mathrm{C}-3$ plants, in addition to its not having the characteristic C-4 anatomy. This was supported by detailed studies on kinetic and enzymological parameters on ribulose 1,5 bis $\mathrm{P}$ carboxylase which was found to be characteristic of C-3 plants. ${ }^{8}$ On the balance of evidence it appears that cassava fixes $\mathrm{CO}_{2}$ by the $\mathrm{C}-3$ pathway. It has also been reported ${ }^{9}$ that $\mathrm{Km}$ values for ribulose 1,5 bis $\mathrm{P}$ carboxylase varied considerably with variety, $7.8-14.0 \mu \mathrm{m}$ for $\mathrm{CO}_{2}$ and $7.5-24.8 \mu \mathrm{m}$ for ribulose bis phosphate indicating a potential \& application in systematics.

Another biochemical factor influencing starch yield appears to be shade induced changes in the ratio of chlorophyll $\mathrm{A}$ to chlorophyll B. ${ }^{10}$

\section{BASIC STUDIES ON THE CYANIDE LIBERATION SYSTEM}

\subsection{Cyanogenic glucosides}

\subsubsection{Nature}

According to surveys at least 2500 species of higher plants contain cyanogenic glucosides. ${ }^{11,12}$ It has been known for a long time that the major cyanogenic glucoside of cassava is linamarin $(\mathbf{I}) \cdot{ }^{13}$ Cassava also contains another cyanogenic glucoside to the extent of $5-10 \%$ total cyanogenic glucoside. This is called lotaustralin (II) ${ }^{14}$ (Figure. 1). Other minor cyanogenic glucosides which have been reported are mentioned later in the review (section 3.1.2). They are all $\beta$-glucosides. ${ }^{15,16}$ These glucosides constitute "Bound cyanide" and appear together in many other plants including flax, clover, lima bean, lotus, ${ }^{15}$ and rubber. ${ }^{17}$
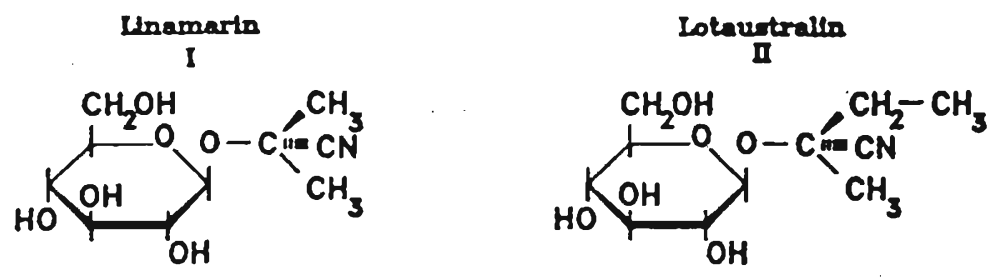

Figure 1: Structures of the major cyanogenic glucosides of Cassava. Linamarin (I) and Lotaustralin (II). 


\subsubsection{Bitterness of cassava}

Varieties of cassava have been historically classified into 3 main classes 4,18 depending on the cyanogenic glucoside content of the edible part of the tuber and on bitterness. The 3 classes are sweet, average toxic and bitter with $<50,50$ 100 and $>100 \mathrm{ppm}$ linamarin calculated as $\mathrm{mg} \mathrm{CN} / \mathrm{kg}$ edible on fresh weight. In fact, bitterness has been considered a guide to the relative toxicity of tubers. However, this may not be as good an indicator as previously believed because cassava has other bitter components. For example, a new apiosyl glucoside (isopropyl(6-0- $\beta$-D-apiofuranosyl)- $\beta$-D-glucopyranoside. ${ }^{19}$ The matter became more complex with the discovery of a third cyanogenic glucoside, a diglycoside $2-(6-0-\beta-D$-apiofuranosyl- $\beta-D$ glucanopyranosyl) oxy-2-methyl butanonitrile in cassava $^{20}$ but this is yet to be confirmed. Nevertheless, others maintain that bitterness in cassava is closely related to its cyanogenic glucoside content. ${ }^{21}$

\subsubsection{Biosynthesis}

$\mathrm{L}$ - valine and $\mathrm{L}$ - isoleucine are the precursors of linamarin and lotaustralin respectively. Their biosynthetic pathway (Fig. 2) was worked out using radioactive tracer techniques. Recent studies ${ }^{25,26}$ describe the isolation of the microsomal enzyme system (multienzyme complex) from the phelloderm of cassava tubers that converts ${ }^{14} \mathrm{C}$ valine into acetone cyanohydrin. The initial step of the sequence (the synthesis of isobutyraldoxime) is said to be catalysed by Cyt-P-450 TYR. This study ${ }^{25}$ also gave important proof that cyanogenic glucosides could be synthesized in the roots as well as the leaf. The leaf is the recognized major site of synthesis of cyanogenic glucosides. ${ }^{22-24,26} \mathrm{Hughes}^{27}$ showed that multiple genes were present to code for UDP-Glucose glucosyl transferase, a soluble cytoplasmic enzyme, which catalysed the last step of the biosynthetic pathway.<smiles>CC(C)C(N)C(=O)O</smiles>

VALINE

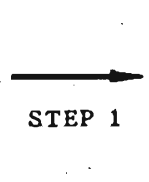

ISOBUTYRALDOXIME<smiles>CC(C)/C=N\O</smiles>

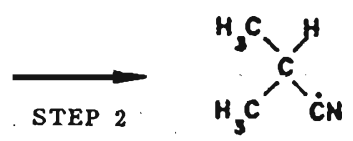

ISOBUTYIZONITRILE

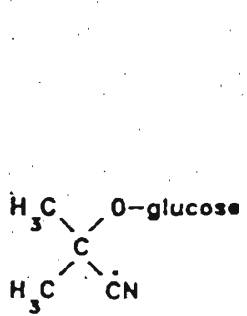

LINAMARIN
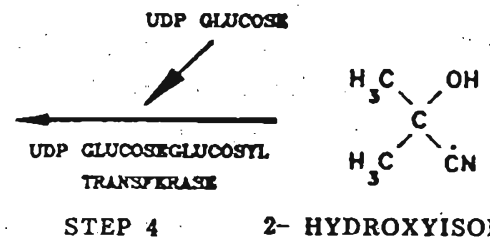

2- HYDROXYISOBUTYRONTTRILE

STEP 3

Figure 2: The biosynthesis of Linamarin. 
Another study ${ }^{26}$ while confirming the microsomal system for biosynthesis, demonstrated that Cyt P-450 was also involved in one of the later steps of the pathway, namely the hydroxylation. It was further shown ${ }^{26}$ that (i) L-valine and L-isoleucine were the only amino acids that can be converted to cyanogenic glucoside by the enzyme system, and (ii) the corresponding oximes and nitriles arising from valine and isoleucine as well as some other oximes and nitriles could also be used as precursors. This study also showed that cyanogenic glucosides were present in all parts of the seedlings used, but the microsomal system occurred only in the cotyledons and petiole. This data supports the translocation theory. Translocation from leaf to root can also be inferred by studies on girdling, where HCN content increased 13 fold above the incision. ${ }^{28}$

\subsection{Linamarase}

\subsubsection{Characteristics}

The review is restricted to the linamarase type of cyanogenic glucosidase and not the emulsin type as it is the former that occurs in cassava. Linamarase is a $\beta$-glucosidase (EC. 3.2.1.21). Linamarase is present in all parts of the plant. The enzyme was obtained in crude form from cassava by Wood ${ }^{29}$ in 1966 and subsequently purified 10-30 fold. ${ }^{30,31}$ These studies resulted in two forms of the enzyme being isolated. At that time these forms were loosely termed isozymes. This was unlikely as the two forms were interconvertible. Later work on Hevea brasiliensis (rubber) showed that these forms were homo-oligomers with molecular weight of sub unit of $64 \mathrm{k} \mathrm{Da} .{ }^{33}$ The rubber seed linamarase was also shown to be very similar if not identical to the manioc linamarase. ${ }^{34}$ Further, the form with the larger number of sub-units was more active. ${ }^{34}$

The intricacies of the enzyme are still being unravelled. Yeoh \& $\mathrm{Sia}^{35}$ reported two forms differing in kinetic properties. While Pong et al. ${ }^{36}$ partially purified three forms which they called isozymes. One of these was located in the cell wall of cassava leaf and was rather non-specific and unusually stable with a temperature optimum of $55^{\circ} \mathrm{C}$. This corresponds to Linamarase D isolated by Peiris $^{37}$ who reported 4 forms of enzymes (A.B.C \& D) with temperature optima of $45,60,60$ and $55^{\circ} \mathrm{C}$ respectively, $\mathrm{pH}$ optima $6.0-6.6$ for the $\mathrm{A} \& \mathrm{~B}$ form and activation energy of 3.3 to $5.7 \mathrm{k} \mathrm{cal} \mathrm{mole}^{-1}$ for the $\mathrm{A}$ and $\mathrm{B}$ form. This was later corrected to $10.8 \mathrm{k} \mathrm{cal}$.mole $\mathrm{e}^{-134}$ based on the criterium that the former study had made the calculation using points too close to the deactivation temperature. It was found that the $\mathrm{B}$ form converts to the $\mathrm{A}$ form with $4 \mathrm{M}$ urea ${ }^{32}$ and the reverse occurs on concentration. ${ }^{34}$ This clearly supports the concept of homo-oligomers.

Recent studies ${ }^{38}$ have confirmed that the linamarase has broad specificity for compounds containing the $\beta$-glucosidic bond. The competitive inhibitor p-nitrophenyl- $\beta-D$-glucopyranoside protected the enzyme from deactivation. 
Using a ${ }^{14} \mathrm{C}$ labelled active site directed inhibitor, followed by hydrolysis and peptide sequencing Glu-198 was identified as a key amino acid at the active site. It has been postulated that a Asn - Glu - Pro motif (pattern) is responsible for hydrolysis. This is also seen in the homologous family $\mathrm{A}$ of $\beta$-glucosidases to which linamarase belongs and family $A_{1}-A_{5}$ of cellulases.

The c-DNA gene for linamarase of white clover has been cloned. ${ }^{39,40}$ The cassava enzyme $\mathrm{e}^{39,40}$ is intracellularly synthesized in the latex vessels of the plant. A study on the immobilized enzyme ${ }^{41}$ showed a variation of $\mathrm{Km}$ and $\mathrm{Vm}$ values, temperature optima and $\mathrm{pH}$ optima.

\subsubsection{The Cyanide liberation process}

\subsubsection{Compartmentation}

Linamarase interacts with linamarin in damaged tissue. The typical $\beta$-glucosidic activity results in acetone cyanohydrin (ethyl methyl ketone cyanohydrin from lotuastralin) which is then acted upon by hydroxynitrile lyase to give the corresponding ketone and $\mathrm{HCN}^{43}$ (Fig. 3). Analytically the cyanohydrin (which decomposes in alkali medium and also on heating to $60^{\circ} \mathrm{C}$ ) and $\mathrm{HCN}$ constitute "free cyanide".

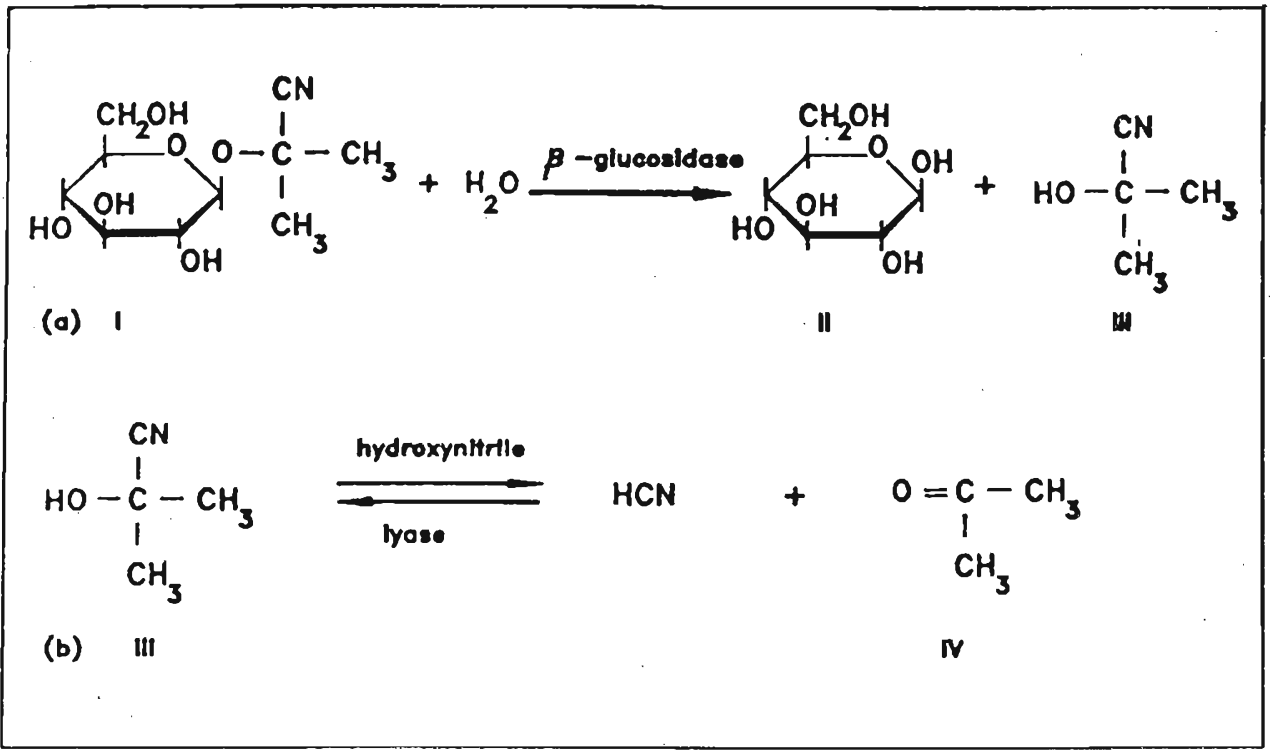

Figure 3: The mechanism of enzymatic decomposition of Linamarin. I - Linamarin, II glucose, III acetone cyanohydrin IV acetone. 
In normal living tissue the enzyme and substrate are found in different subcellular compartments. ${ }^{44}$ Gruhnert \& Biehl ${ }^{45}$ showed that in Hevea brasiliensis and six other cyanogenic species, linamarase activity was present in the cytoplasmic fluid while linamarin was located extensively in the central vacuole. They however found no evidence of a diglucosidase capable of hydrolysing the diglucosides linustatin and neolinustatin ${ }^{46}$ in the cytoplasmic fluids. Linustatin and neolinustatin are said to be trasportable diglucoside forms of the cyanogenic glucoside in question. The presence of these diglucosides was earlier postulated as the basis of a mechanism for translocation across the cell wall before linamarin could be transported to the roots. ${ }^{36}$

\subsubsection{Role of hydroxynitrile lyase}

The product of linamarase action is a hydroxynitrile. This is unstable to heat and alkali medium and therefore, for analytical purposes, hydroxynitrile lyase is not required. The plant has a hydroxynitrile lyase to liberate $\mathrm{HCN}$ from acetone cyanohydrin. It is probably due to the lability of the substrate that this enzyme has not been subject to more intensive investigation. The hydroxynitrile lyase of cassava increases by 20 fold the rate of liberation of cyanide. ${ }^{42}$ It is capable of adding HCN to several aliphatic carboxyls ${ }^{48}$ and has a molecular weight of $30 \mathrm{k}$ Da with serine residues at the active site. It has been shown that cassava hydroxynitrile lyase has no serological relationship with other acetone cyanohydrin lyases. ${ }^{48}$ Unlike linamarase this lyase is present only in very low levels in the latex vessels and therefore must be predominantly located elsewhere in the leaf. ${ }^{44}$

\subsection{Assay of cyanogenic glucosides}

Early assays involved acid hydrolysis. This has subsequently been proved to be time consuming and inaccurate. ${ }^{34,49,50}$ This aspect has been reviewed previously ${ }^{49}$ and is therefore not detailed in this review. It is now generally accepted that the use of linamarase as hydrolytic agent, as opposed to acid, constitutes the superior technique. This is usually followed by a colorimetric assay. Picrate, first used quantitatively for cyanogenic glucoside assay by Wood ${ }^{29}$ is the most commonly used colour reagent. The combination of exogenous linamarase hydrolysis, distillation and determination of total cyanide (free plus bound) by picrate was first used on cassava in $1973^{51}$ and was found to be widely applicable. The test included the use of exogenous linamarase which was incubated with the cassava based material. This was followed by water distillation and collection in sodium carbonate. Aliquots were tested for cyanide with alkaline picrate for quantification. ${ }^{51}$ It was imperative that exogenous linamarase be used especially with processed manioc products. ${ }^{52}$ If attention is concentrated on the newer techniques, the following appear most worthy of note. 
Electrochemical methods have been developed ${ }^{53}$ to assay both glucosidic bound and non-glucosidic cyanide groups. In the latter instance, the values obtained were significantly higher than that of colorimetric methods probably reflecting cyanohydrins. Immobilization techniques were also used to bind linamarase to an activated 2-fluoro-N-methyl, pyridinium fractogel support to assay total cyanide. ${ }^{54}$ This has the advantage that interference from glucose and acetone was negligible to the alkaline picrate reaction ${ }^{54}$ which was used for final quantification. Presumably this also prevents the interference by Maillard browning pigments. ${ }^{55}$ Quantitative analysis of linamarin has been reported using a $\beta$-glucoside electrode in the range of $24-355 \mathrm{mg} / \mathrm{kg}$ fresh weight and yielded values comparable to the spectrophotometric method. ${ }^{56} \mathrm{~A}$ microdiffusion solid method was also reported to determine cyanogenic glucosides in human urine. ${ }^{57}$ Rapid screening of cassava varieties for $\mathrm{CN}^{-}$content of the tuber has been reported. ${ }^{58}$ This involved the use of filter paper impregnated with tetra-base (4,4' methylene bis(N,N-dimethyl aniline) and cupric acetate.

Among the other assays has been solvent extraction to estimate cyanide, cyanohydrins and cyanogenic glucosides separately ${ }^{59}$ and in the process doing away with the need for distillation.

\section{Effect of processing on cyanogenic glucosides and cyanogenesis}

\subsection{Scope}

The general area of study is extremely wide and initially had been focussed on processing in Africa where washed, macerated and fermented products are widely consumed e.g. as "gari" and "farina". Due to the nature of the processing, these food products have relatively low cyanogenic glucoside content. In this review it is intended to cover only the more recent publications (1985 - 1996) on this type of processing.

In Sri Lanka, fermented products are unknown as food and traditionally cassava is boiled and less often fried before consumption. It is of historical interest that in the mid 1970s cassava was seriously considered as a large scale supplement for wheat and rice. From this concept arose a family of products based on manioc chips and flour ${ }^{30,60}$ and this together with the potential use as food or feed aroused interest in the effect of processing of cassava chips and flour derivatives on cyanogenic glucoside content. Although this has been extensively published in Sri Lanka ${ }^{30,49,60,61}$ it appears that it is not very well known by scientists outside the country and is worth summarising (Section 4.3). 


\subsection{Recent studies on fermented products}

\subsubsection{Fermentation}

The basic approach in Africa is to allow endogenous enzymes and microbial enzymes to react with the cassava (to ferment) and then drive off the cyanide formed by a heating step. It has been reported from $\mathrm{Nigeria}^{62}$ that fermentation time affected the cyanogenic glucoside content very significantly. Another study $^{63}$ showed that during fermentation the pseudo-kinetic constant for the decay of bound cyanide was $1.6 \times 10^{-2} \mathrm{~h}$ while that for the release of free cyanide was $2.5 \mathrm{~h}$. Release of HCN was therefore rate limiting with 'farina' and 'baton' in the Cameroons. ${ }^{64}$ It was found that traditional processing resulted in considerable loss of total cyanide during the fermentation and pressing stages. There was however a transient increase in intermediates (cyanohydrins) and free cyanide which was removed mainly during the sun drying and cooking stages. However shortening of processing time due to food shortages have caused increased $\mathrm{CN}^{-}$content and paralytic disease ${ }^{65}$

\subsubsection{Effect of specifically introduced microorganisms}

Recent research trends concentrate on the microbial aspects of detoxification of cassava by specifically introduced microorganisms. Detoxification of cassava pulp has been reported ${ }^{66}$ using Brevi-bacterium sp. $\mathrm{R} 312$ which has extracellular $\beta$-glucosidases, hydroxynitrile lyase and amidase.

Another report ${ }^{67}$ showed that 6 out of 10 lactic acid bacterial strains tested exhibited linamarase activity. The highest activity was shown by Lactobacillus plantarum strain A6. The products of hydrolysis were lactic acid and acetone cyanohydrin. A similar detoxifying action was reported using a mixed culture innoculum. ${ }^{68}$ However Ampe et al.$^{69}$ concluded that detoxification occuring in fermentations was mainly due to linamarase arising from the tuber though exogenous microbial $\beta$-glucosidases may also act.

Several fungi and bacteria capable of hydrolysing linamarin to HCN have been isolated from Ugandan cassava ${ }^{70}$ and appear to play a role in solidsubstrate fermentation of cassava. The microbes included a Bacillus species which reduced linamarin by $99 \%$ in $72 \mathrm{~h}$. Using a rather different approach, viz., anaerobic digestion of cassava by methanogenic microflora it was shown ${ }^{71}$ that cassava detoxification proceeded by the successive action of linamarase and $\beta$-cyanoalanine synthase. 


\subsection{Sri Lankan studies on total cyanide in cassava products}

In contrast to Africa, the general approach to processing in South Asia has been to deactivate Linamarase by boiling. This has been described in the $\mathrm{Ph} . \mathrm{D}$ thesis of Pieris ${ }^{30}$ and summarises the loss of glucoside using various processing techniques.

\begin{tabular}{lc}
\hline Product & Loss of cyanogenic glucoside $(\%)$ \\
\hline Boiled cassava & $50-70$ \\
Cassava flour & $30-70$ \\
(slow drying of chip) & $0-30$ \\
Cassava flour & \\
(fast drying of chip) & 95 \\
Detoxified cassava flour & 95 \\
Cassava starch & $0-10$ \\
Fried cassava chips &
\end{tabular}

Cassava flour products e.g. bread, roti, pittu contained $20-30 \%, 30-70 \%$ and $70-100 \%$ respectively of the total cyanide contained in the flour from which they were made. ${ }^{30}$

The overall conclusion is that: (i) in the dry state the enzyme is not active; (ii) incubation with water or high moisture in the chip or flour results in linamarase activity; (iii) heat denatures the enzyme thus stopping cyanide release and therefore a possible retention of cyanogenic glucoside levels. Cassava starch and detoxified manioc flour have less than $5 \mathrm{ppm}$ total cyanide. ${ }^{61}$

\subsection{More recent studies relevant to Sri Lanka}

\subsubsection{Effect of moisture}

The above findings were re-confirmed by a study in India ${ }^{71}$ which showed that $>80 \%$ of the cyanogenic glucoside was retained in baked, fried and steamed tuber while the value in chips was $24-75 \%$, whereas crushing the tuber followed by sun drying caused the elimination of $95 \%$ of the cyanogenic glucoside, showing that retention of moisture was crucial for liberation of cyanide. The effective use of water and solvents was further underlined in a report stating that while water increased linamarase action, frying in palm oil may remove $>90 \%$ of the cyanohydrins and cyanogenic glucosides. ${ }^{47}$

In another study it was underlined that moisture was a crucial factor in the loss of cyanide from cassava chips. The maximum loss of cyanide was at $60^{\circ} \mathrm{C}$. This was increased by air circulation and reduced by rapid dehydration at higher temperature. ${ }^{73}$ 


\subsubsection{Effect of disintegration}

Studies on drying cassava chips ${ }^{74,75}$ confirmed earlier studies ${ }^{30}$ and also showed that smaller chip size favoured reduction in cyanogenic glucoside content. Mincing and rasping (procedures used in starch production) caused loss of 100 and $70-80 \%$ respectively of cyanogenic glucoside content.

\subsection{Summary on processing}

It is clear that the strategy for manioc utilization in Africa is to ferment and convert all cyanogenic glucoside to $\mathrm{HCN}$ (free cyanide) and then to drive off $\mathrm{HCN}$ by cooking or drying. ${ }^{3,4}$ On the other hand in South Asia the main strategy is to destroy linamarase and prevent $\mathrm{HCN}$ formation. The latter causes the presence of considerable residual cyanogenic glucoside (bound cyanide). This gave rise to two questions : (i) Is the glucoside in itself toxic? (This is discussed later in the review) and (ii) Is it possible that gut flora or enzymes from other uncooked plants can liberate cyanide after ingestion?

Studies on microbes, point to this possibility as many microbes have been shown to have linamarase hydrolysing capability ${ }^{62-64,65-69}$; can similar ones exist among gut flora ${ }^{76}$ ? The vegetables Alternanthera sessilis (Sinhala: Mukunuwenna) and Ipomea aquatica (Sinhala: Kankun) have this property. ${ }^{76}$ The folklore surrounding ginger (Zingiber officinale) is more complex. It appears that although ginger is capable of slow release of cyanide from boiled manioc, this activity is not shown on purified linamarin. ${ }^{76}$ Further Psidium gauva (guava) has a potent inhibitor for linamarase..$^{76}$

\section{Toxicity studies}

\subsection{Acute toxicity}

Acute toxicity from cassava in humans is extremely rare. It is due to HCN (prussic acid) inhibiting metalloenzymes, notably on $\mathrm{Cu}^{+}$in the cytochrome oxidase system ${ }^{77}$ and $\mathrm{Fe}^{3+}$ of cytochromes, thus crippling the respiratory chain. The lethal dose of cyanide in adult humans is $50-60 \mathrm{mg}^{78}(0.5-3.5 \mathrm{mg} / \mathrm{kg}$ body weight). The lethal dose in animals varies. ${ }^{79}$ The reason why cyanide poisoning is not common in Sri Lanka is probably because the mean cyanide content of cassava was $100 \mathrm{mg} / \mathrm{kg}$ in the mid $1970 \mathrm{~s}^{30}$; and has fallen to about half that value in the $1990 \mathrm{~s} .{ }^{80}$ This is probably due to varietal selection. Further in boiled cassava (i) approximately $50 \%$ total cyanide is lost and (ii) the plant linamarase is destroyed. Therefore even if all the remaining bound glucoside is converted to free cyanide (a very unlikely situation), it would require a quantity of $2-3 \mathrm{~kg}$ cassava to be consumed in a meal to cause death. 


\subsection{Chronic toxicity}

More serious is chronic toxicity of cassava due to repeated oral ingestion of sublethal doses. For example, boiled cassava contains up to $5 \mathrm{mg} / \mathrm{kg}$ free cyanide. ${ }^{30}$ Repeated daily doses of this magnitude over a period of time is reported to cause chronic toxicity of various forms which have been extensively reviewed elsewhere. ${ }^{81-83}$ Essentially, the diseases reported include goitre ${ }^{82-84}$ cretinism $^{85}$ tropical ataxic neuropathy, ${ }^{86}$ Lebers optic atropy, ${ }^{87}$ pancreatic diabetes ${ }^{88}$ and Konzo. ${ }^{89}$ While goitre, cretinism and ataxic neuropathy are caused by overload of thiocyanate (CNS $)^{-}$which is a detoxification product (see section 5.3), Leber's optic atropy is a genetic disorder caused by the inability to detoxify $\mathrm{CN}^{-87}$ Pancreatic diabetes and tropical pancreatitis is reported to appear in subjects consuming cassava with insufficient protein in their diet. ${ }^{88}$ Konzo which is caused by a lack of nutritional sulphur is an upper motor neuron disease reported in Zaire (East Africa) in those consuming bitter cassava. ${ }^{89}$ The primary goitrogenic action of CNS- is its effect on the $\mathrm{I}^{-}$pump.$^{82}$

\subsection{Detoxification mechanisms for $\mathrm{HCN}$}

In plants, the primary reactions are catalysed by rhodanese ${ }^{90}$ (which converts cyanide to thiocyanate using thiosulphate) and $\beta$-cyanoalanine synthase. ${ }^{24}$. The $\beta$-cyanoalanine (a neurotoxin) can be converted to asparagine by $\beta$-cyanoalanine hydrolase..$^{91}$

In Plant

(a) $\mathrm{CN}^{-}+\mathrm{S}_{2} \mathrm{O}_{3}{ }^{2-} \stackrel{\text { Rhodanese }}{\longrightarrow} \mathrm{CNS}^{-}+\mathrm{SO}_{3}{ }^{2-}$

(b) $\mathrm{HCN}+$ Cysteine $\stackrel{\beta \text {-cyanoalanine synthase }}{\longrightarrow} \beta$-cyanoalanine $+\mathrm{H}_{2} \mathrm{~S}$

$$
\mathrm{H}_{2} \mathrm{O}+\text { Cyanolanine } \stackrel{\beta \text {-cyanoalanine hydrolase }}{\longrightarrow} \text { Asparagine }
$$

In Animals

(c) Cystine $+\mathrm{CN}^{-} \longrightarrow$ 2-amino-thiozoline-4-carboxylic acid + cysteine (Direct Method)

(d) Cysteine $\longrightarrow$ Mercaptopyruvate $\longrightarrow$ CNS + Pyruvate Transamination

Sulftransferase

(Indirect Method)

(e) Vitamin $\mathrm{B}_{12} \stackrel{\mathrm{CN}^{-}}{\longrightarrow}$ Cyanocobalamin 
In animals, ingested cyanide is detoxified in a number of ways including the use of sulpho-amino acids directly ${ }^{92}$ and indrectly, ${ }^{92,94}$ by rhodanese, and reaction with vitamin $\mathrm{B}_{12}{ }^{95}$ Detoxification therefore : (i) is efficient in a subject with adequate protein intake, (ii) can cause a depletion of sulphoamino acids and Vitamin B and (iii) give rise to products that can cause chronic toxicity (CNS-) ${ }^{93}$

Thiocyanate can be converted to cyanide in erythrocytes by thiocyanate oxidase $^{96}$ and thus an equilibrium for $\mathrm{CN}^{-}$is established at a ratio of 99:1.

\subsection{The Fate of ingested cyanogenic glucoside}

\subsubsection{Early studies}

This is an area where some uncertainty exists. Humans fed on $11 \mathrm{mg}$ of linamarin showed no toxic effects. ${ }^{77}$ Other studies showed that linamarin is absorbed by the digestive tract and at least a part passes out in the urine. ${ }^{71}$ Bourdoux et al..$^{77}$ also showed that Klebsiella species could hydrolyse linamarin, although no mention of the product is made.

Increased thiocyanate occurs in the serum and urine and I uptake is decreased only when both linamarin and linamarase are ingested. ${ }^{77}$ This indicates that in the absence of a $\beta$-glucosidase, gut bacteria may be involved in converting linamarin to another metabolite. The high levels of CNS reported in serum and urine in some subjects consuming high levels of cassava flour containing very low levels of $\mathrm{CN}^{-77}$ suggests a mechanism to convert the glucoside to cyanide probably by gut flora. This is plausible since many microbes have been shown to have linamarin hydrolysing activity (Section 4.2).

\subsubsection{A Sri Lankan study}

Amarasinghe ${ }^{97}$ synthesized a ${ }^{14} \mathrm{C}$ - labelled linamarin with the label in the $\mathrm{CN}$ moiety. This was fed to rats, and a number of interesting observations were made viz.:

(i) As with the studies of Barrett ${ }^{98}$ and Bourdoux et al. ${ }^{77}$ linamarin appeared in the urine. (ii) No radioactive carbon appeared in the faeces showing complete absorption (iii) ${ }^{14} \mathrm{CN}^{-}$and ${ }^{14} \mathrm{CNS}^{-}$were not observed in the blood. (iv) $\mathrm{A}^{14} \mathrm{C}$ metabolite (other than linamarin) also appeared first in the portal circulation then in the peripheral circulation, and finally in the urine. (v) The bulk of the ${ }^{14} \mathrm{C}$ was not excreted in 6 days. (vi) The metabolite isolated in the blood had ${ }^{14} \mathrm{C}$ in a - $\mathrm{COOH}$ group. From this Amarasinghe ${ }^{97}$ proposed the following theory. 
Intestine

\section{Portal}

Circulation

(6h)

Urine

Circulation

(3 days)

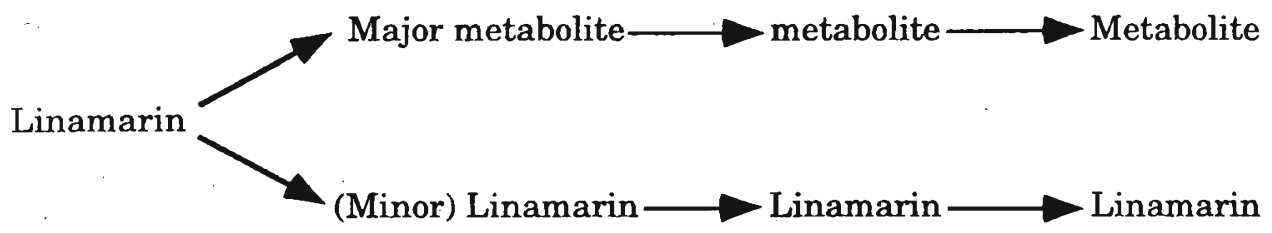

The metabolite was not identified but a number of useful conclusions could be made : (i) linamarin is absorbed by the gut, (ii) it is converted to a metabolite where the $\mathrm{CN}$ moiety is converted to $\mathrm{COOH}$ or $\mathrm{CONH}_{2}$ (by intestinal cells or gut bacteria) and (iii) the bulk of the metabolite is probably catabolised or converted to cellular molecules.

Another explanation could be that linamarin is converted to $\mathrm{CN}^{-}$by intestinal or gut flora enzymes which in a fast reaction could be converted to $\beta$-cyanoalanine by a $\beta$-cyanoalanine synthase-like enzyme and then by $\beta$ - cyanoalanine hydrolase to asparagine and finally incorporated into cellular materials.

\subsubsection{Effects of cassava diets}

More recently a study ${ }^{99}$ showed that feeding of cassava to humans resulted in increase of serum CNS and a loss of $28 \%$ of the total cyanide in urine in 24 hours. However CNS could have arisen from free $\mathrm{CN}$. The presence of a mean $211 \mu \mathrm{mole} / \mathrm{l}$ cyanogenic glucoside in the urine is reported ${ }^{51}$ in a study from Mozambique.

Hernandez ${ }^{99}$ also reported that when human subjects consumed $1-4 \mathrm{~kg}$ of cassava over 2 days that showed a small increase of urinary CNS while the major effect was increased urinary excretion of cyanogenic glucoside.

It has also been reported ${ }^{100}$ that increased thiamin status decreased CNSlevels in serum while there was no change in linamarin in urine. Serum antibody tests ${ }^{101}$ showed that rats fed on gari at a $80 \%$ level showed small but significant increases in glycosylated haemoglobin and erythrocyte free fatty acids. They suggested the use of these measurements in determining diabetogenic effects. A study on rabbits showed that cassava diets increased cholesterol and lactic acid in liver and brain, caused a depletion of phospholipids and caused changes in isozyme patterns. ${ }^{103}$ 
Considerable change in behavioural patterns in swine including reduced aggressiveness and limb stiffness were reported after continued cassava consumption. Biochemical features of diminished thyroid hormones $\mathrm{T}_{3}$ and $\mathrm{T}_{4}$ and increased fasting blood sugar were reported. ${ }^{103}$

In summary, it appears that in humans there is no doubt that the cyanogenic glucoside is absorbed by the intestine. It has been proved that at least part of the cyanogenic glucosides pass unhydrolysed in the urine. However there appears to be other fates for the compounds including conversion to $\mathrm{CN}^{-}$and then CNSor by being retained in cellular molecules after conversion by gut flora or endogenous enzymes, into substances like asparagine (section 5.3 pathway b).

\section{Nutritive value}

It has long been recognised that the only major component of nutritive value in the tuber is starch. ${ }^{3,30}$

The proximate analysis of cassava tuber ${ }^{105}$.given on the basis of $\mathrm{g}^{100 \mathrm{~g}^{-1}}$ edible is :-

$\begin{array}{ll}\text { Moisture } & 59.4 \\ \text { Total Carbohydrate } & 38.1 \\ \text { Lipid } & 0.2 \\ \text { Protein } & 0.7\end{array}$

There are naturally variations, with moisture ranging from 58 to $65 \%$ and starch from 30 to $35 \% .^{3,30}$

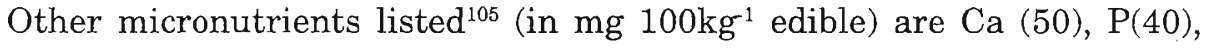
$\mathrm{Fe}(0.9)$, Niacin (0.3), Vitamin C (25), Thiamin (0.05) and Riboflavin (0.1). Carotenoid content varies greatly with cultivar and is dealt with below. Cassava leaf however, has considerable protein. ${ }^{106}$

Cassava starch is highly digesible and shows no signs of significant $\alpha-1-2$ and $\alpha-1-3$ bonds as evidenced by its hydrolysis to glucose at nearly theoretical yields by the industrial enzymes, $\alpha$-amylase (Ex. B. licheniformis), amyloglucosidase and pullulanase. ${ }^{107}$ Starch in cassava bread showed a high degree of hydrolysis by pancreatic $\alpha$-amylase. ${ }^{108}$ However, the digestibility index according to the digestion/dialysis model was relatively low. The latter was attributed to the viscosity of the medium. ${ }^{108}$ On the other hand, boiled and oven dried cassava was found to be highly digestible to infants and small children. ${ }^{109}$ The glycaemic index of cassava flour like other starchy tubers was found to be high. ${ }^{110}$ 
Dietary fibre content was found to be 4.92 to $5.6 \%$ for insoluble fibre and 3.40 to 3.78 for soluble fibre. ${ }^{108}$ The dietary fibre has been characterized and found to be similar to potato starch. ${ }^{111}$

The only other nutritive component worthy of mention is $\beta$-carotene which was found to be highly variable among germplasm, namely $0.04-0.75 \mathrm{mg} 100 \mathrm{~g}^{-1}$ (40-750 retinol) equivalents $-100 \mathrm{~g}^{-1}$ edible in India ${ }^{112}$ and 0.33 to 55.67 retinol equivalents $100 \mathrm{~g}^{-1}$ edible in Brazil. ${ }^{113}$ In the latter case it comprised neo$\beta$ - carotene $B$, trans $\beta$-carotene and neo- $\beta$ carotene $U$.

\section{Conclusion}

The area of cassava biochemistry is vast. It has been the purpose of this review to provide the background to the subject and to highlight Sri Lankan work in the perspective of current (1985-1996) knowledge on the subject. Mentioned only in passing in the review are subject areas that have been extensively reviewed previously such as the IDRC and CIAT sponsored work on chronic cassava toxicity, quantitative assays for cyanide and agricultural aspects.

\section{References}

1. Centro International Agricultura Tropical (1979). Cassava programme annual report. Cali, Colombia. pp. 5-87.

2. Cerighelli, R. (1955). Plantes vivrieres. Cultures Tropicales, Libraire Bailliere et Fils, Paris, pp. 289-378.

3. Jones W.O. (1959). Manioc in Africa. Stanford University Press, Stanford, Calif., U.S.A. pp. 3-36.

4. De Bruijn G.H. (1971). Etude du caractere cyanogenetique du manioc (Manihot esculenta Crantz). Mededelingen Landbouwhoge Schol Wageningen-Nederlands. pp. 1-140.

5. Sharkawy E.I., Mabrouk A \& Cock J.H. (1990). Photosynthesis in cassava (Manihot esculenta). Experimental Agriculture 26 : 325-340.

6. Cock J.H., Riano N.M., Sharkawy E.I., Mabrouk A., Lopez F.Y., \& Bastidas G. (1987). I. C3 - C4 intermediate photosynthesis characteristics of cassava. (Manihot esculenta Crantz) II. Initial products of ${ }^{14} \mathrm{C}$ - carbon dioxide fixation. Photosynthetic Research 12 : 237-241. 
7.' Edwards G.E., Sheta E.M., Brandon D. Dai Z., Franceshi V.R., Cheng S.H., Lin C.H., Ku M.S.B. (1991). Photosynthetic characteristics of cassava (Manihot esculenta Crantz). Biotechnology Letters 13 : 697-700.

8. Paul K. \& Yeoh H. (1989). Activation of ribulose 1,5 bis P carboxylase of cassava leaves. (Manihot esculenta Crantz). Acta Physiol Planta 11 : 31-38.

9. Paul K. \& Yeoh H. (1987). Km values of ribulose 1,5 bis $\mathrm{P}$ carboxylase of cassava cultivars. Phytochemistry 26 : 1965-1967.

10. Ramanujam T. \& Jos J.S. (1984). Influence of light intensity on chlorophyll distribution and anatomical characters of cassava leaves. Turrialba. 34: 467-471.

11. Eyjolfsson R. (1970). Recent advances in the chemistry of cyanogenic glucosides. Fortschritte der chemie organ - Naturstoffe 28 : 74-108.

12. Nartey F. (1978). Mahihot esculenta - cyanogenic ultrastructure and seed germination. Villadsen and Christensen, Copenhangen. pp. 17-109.

13. Dunstan W.R., Henry T.A. \& Auld S.T.M. (1906). Cyanogenesis in plants. The occurrence of phaseolunatin in cassava. (Manihot aipi \& Manihot utilissima). Proceedings of the Royal Society London B 78: 152-158.

14. Nartey F. (1968). Studies on cassava. Manihot utilissima Phol I. Cyanogenesis. The biosynthesis of linamarin and lotaustralin in etiolated seedlings. Phytochemistry $7:$ 1307-1312.

15. Butler G.W. (1965). The distrubution of the cyanoglucosides linamarin and lotaustralin in higher plants. Phytochemistry 4 :127-131.

16. Clapp R.C., Bissett F.H., Coburn R.A. \& Long J.R. (1966). Cyanogenesis in manioc : linamarin \& isolinamarin. Phytochemistry 5: 1323-1326.

17. Mallika G.V., Jansz E.R. \& Pieris N.M (1991). The cyanogenic glucosides \& glucosidases of rubber seed kernel. Journal of the National Science Council Sri Lanka 19 : 99-106.

18. Bolhuis G.G. (1954). The toxicity of cassava roots. Netherlands Journal Agricultural Science 2 : 176-185.

19. King N.L.R. \& Bradbury J.H. (1995). Bitterness of cassava: identification of a new apiosyl glucoside \& other compounds that effect its bitter taste. Journal of Science of Food and Agriculture 68 : 223-2230. 
20. Prawat H., Mahidol C., Ruchirwat S. \& Prawat U. (1995). Cyanogenic and non-cyanogenic glucosides from Manihot esculenta. Phytochemistry 40 : 1167- 1173.

21. Sundaresan S., Nambisan B.A. \& Easwari C.S. (1987). Bitterness in cassava in relation to cyanide content. Indian Journal of Agricultural Science $\mathbf{5 7}$ : $37-40$.

22. Conn E.E. \& Butler G.W. (1969). The biosynthesis of cyanogenic glucosides \& other simple nitrogen compounds. In: Perspectives in phytochemistry. (Ed. J.B. Harborne \& T. Swain) Chap 2 : pp. 47-74.Academic Press, London.

23. Tapper B.A., Zilg H. \& Conn E.E. (1972). 2 - Hydroxyaldoximes as possible precursors in the biosynthesis of cyanogenic glucosides. Phytochemistry 11: 1047-1053.

24. Nartey F. (1969). Studies on Cassava, Manihot utilissima. II. Biosynthesis of asparagine $-{ }^{14} \mathrm{C}$ from ${ }^{14} \mathrm{C}$ - labelled hydrogen cyanide \& its relation with cyanogenesis. Physiology of Plants 22: 1085-1096.

25. Du. L \& Bokango M. (1995). The biosynthesis of cyanogenic glucosides in roots of cassava. Phytochemistry $39: 323-326$.

26. Koch B. \& Cerl E. (1992). The biosynthesis of cyanogenic glucosides in seedlings of cassava. Archives Biochemistry and Biophysics 92 : 141-150.

27. Hughes J. \& Hughes M.A. (1994). Multiple secondary plant product UDP glucose glucosyl transferase genes expressed in cassava. (Manihot esculenta Crantz) cotyledons. DNA sequence 5 : 4.1-49.

28. Ramanujan T. \& Indira P. (1984). Effect of girdling on the distribution of total carbohydrate and hydrocyanic acid in cassava. Indian Journal of Plant Physiology 27 : 355-360.

29. Wood T. (1966). The isolation, properties and enzymic breakdown of linamarin from cassava. Journal of Science of Food and Agriculture 17 : 85-90.

30. Pieris N.M. (1976). Studies on the cyanogenic glucosides and glucosidases of Manihot esculenta Crantz. Ph.D. Thesis, University of Colombo.

31. Cooke R.D., Blake G.G. \& Battershill J.M. (1978). Purification of cassava linamarase. Phytochemistry $17: 381-383$. 
32. Pieris N.M. \& Jansz E.R. (1976). Cyanide liberation from linamarin. II. Purification \& some properties of the cyanide liberating enzymes of manioc rind. Journal of the Natural Science Council, Sri Lanka 4:29-47.

33. Selmar D., Reinhard L., Bole B. \& Jurgen V. (1987). Hevea linamarase - a non-specific $\beta$ - glycosidase. Plant Physiology 83 : 557-563.

34. Mallika G.V. (1991). Applied chemical studies on rubber seed to support its industrial utilization. M.Phil thesis, University of Sri Jayewardenepura.

35. Yeoh H.H. \& Sia H.L. (1989). $\beta$ - Glucosidases of cassava leaves. Acta Physiol Planta 11 : 187-192.

36. Pong M.K., Offiong E., Yeoh H., Chism G. \& Sayre R.T. (1990). Purification, characterization \& localization of linamarase in cassava. Plant Physiology 93 : $176-181$.

37. Pieris N. \& Jansz E.R. (1976). Cyanide lliberation from linamarin. III. Separation of the linamarases of manioc rind by DEAE-cellulose chromatography. Journal of the National Science Council, Sri Lanka 4: 139-147.

38. Keresztessy Z. \& Kiss L. (1994). Investigation of the active site of the cyanogenic $\beta$-glucosidase (Linamarase) from Manihot esculenta Crantz (cassava). II. Identification of Glu-198 as an active site carboxylate group and acid catalytic function. Archives Biochemistry and Biophysics 315: 323-330.

39. Hughes M.A. (1992). Molecular genetics of plant cyanogenic $\beta$-glucosidases. Asian Chemical Sciences Symposium series 533 ( $\beta$-glucosidases). pp. 153169.

40. Hughes J., Hughes M.A., Sharif A.L., Dunn M.A. \& Oxtoby E. (1988). The molecular biology of cyanogenesis. Ciba Foundation Symposium 140 : 111130.

41. Yeoh H.H. (1991). Kinetic properties of cassava $\beta$ - glucosidase immobillized in photo-crosslinkable resins. Biotechnology Letters 13: 697-700.

42. Conn E.E. (1969). Cyanogenic glucosides. Agricultural Food Chemistry 17: $519-526$.

43. Selmar D., Lieberei R., Biehl B. \& Conn E.E. (1989). Hydroxynitrile lyase in Hevea brasiliensis \& significance for rapid cyanogenesis. Physiology of plants 75: 97-101. 
44. Pancon A. \& Hughes M.A. (1992). In situ locallization of cyanogenic $\beta$-glucosidase (linamarase) gene expression in leaves of cassava Manihot esculenta Crantz using non-isotopic probes. Plant Journal 2: 821-827.

45. Gruhnert C. \& Biehl B. (1994). Compartmentation of cyanogenic glucosides and their degradation enzymes. Planta $195: 36-42$.

46. Selmar D., Lieberei R., Junqueira N. \& Biehl B. (1991). Changes in cyanogenic glucoside content in seeds \& seedlings of Hevea sp. Phytochemistry 30 : 2135-2140.

47. Fomunyam R.T., Adegble A.A. \& Oke O.L. (1985). The stability of cyanohydrins. Food Chemistry $17: 221-225$.

48. Wajant H. \& Forester S. (1995). Acetone cyanohydrin lyase from Manihot esculenta (cassava) is serologically distinct from other hydroxynitrile lyases. Plant Science 108: 1-11.

49. Jansz E.R. \& Nethsingha C.L.M. (1973). Manioc : selected topics Journal of the National Science Council, Sri Lanka 1: 83-96.

50. Mallika G.V., Jansz E.R. \& Pieris N.M. (1993). Problems associated with the estimation of cyanide in rubber seed kernel. Journal of the National Science Council, Sri Lanka 21 :153-156.

51. Pieris N., Premadasa G.G. \& Jansz E.R. (1973). A method for assay of total potential cyanide in manioc flour. Journal of National Science Council of Sri Lanka 1: 207-210.

52. Pieris N., Jansz E.R. \& Kandage R. (1974). Cyanogenic glucoside content of manioc. I. An enzymic method of determination applied to processed manioc. Journal of the National Science Council, Sri Lanka 2 : 67-76.

53. Dolezal M. \& Fatal S.A. (1993). Determination of cyanogenic glucosides of cassava (Manihot esculenta) and cassava products. Potravinvedy 11: 163170.

54. Narinesingh D., Jaipersad D. \& Chang Yen I. (1988). Immobilization of linamarase and its use in the determination of bound cyanide in cassava using flow injection analysis. Analytical Biochemistry 127 :89-95

55. Arihantana M.B. \& Buckle K.A. (1986). Effect of non-enzymic browning of starch and sugars on total cyanide determination in cassava by enzymic assay. Journal of Food Technology 21: 189-197. 
56. Yeoh H.H. \& Truong V:D. (1993). Quantitative analysis of linamarin in cassava using a cassava $\beta$ glucoside electrode. Food Chemistry $47: 295-298$.

57. Beimer L. \& Rosling H. (1993). Microdiffusion method and solid state destruction of cyanogenic glucosides from cassava in human urine. Food Chemistry and Toxicology $31: 599-603$.

58. Beadbury J., Howard E. (1992). Rapid screening assay of cyanide content of cassava. Phytochemical Analysis 3 : 91-94.

59. O'Brien G.M., Taylor A.J. \& Poulter N.H. (1991). Improved enzymic assay for cyanogens in fresh and processed cassava. Journal of Science of Food and Agriculture 56 : 277-289.

60. Pieris N. \& Jansz E.R. (1975). Cyanogenic glucoside content of manioc. III. Fate of bound cyanide on processing and cooking. Journal of the National Science Council, Sri Lanka 3 : 41-50.

61. Jansz E.R., Pieris N. \& Abeyratne D.J. (1974). Cyanogenic glucoside content of manioc. II. Detoxification of manioc chips \& flour. Journal of the National Science Council, Sri Lanka 2 : 129-134.

62. Ukhun M.E. \& Nkowocha F.O. (1989). The HCN content of gari flour made from cassava, (Manihot sp.) and the influence of length of fermentation and location of source. Food Chemistry 33: 107-113.

63. Otuya C.O., Ukpong E. \& Adesina A.A. (1989). Modelling of the rate date from the fermentation of cassava slurry. Letters in Applied Microbiology 9: 13-16.

64. O'Brien G.M. \& Mbome L. (1992). Variation in cyanogen content of cassava during village processing in Cameroons. Food Chemistry 44 : 131-136.

65. Milingi N.V., Assey V.D., Swai A.B.M., McLaren D.G., Karlen H. \& Rosling H. (1993). Determinants of cyanide exposure from cassava in a known affected population in Northern Tanzania. International Journal of Food Science and Nutrition $44: 137-144$.

66. Legras J.L., Jory M., Arnaud A. \& Galzy P. (1990). Detoxification of cassava pulp using Brevi-bacterium sp. R312. Applied Microbiology and Biotechnology 33 : $529-533$.

67. Girand E. \& Goselin L.(1992). Degradation of cassava linamarin by lactic acid bacteria. Biotechnology Letters 14 : 593-598. 
68. Padmaja G. \& George M. (1993). Detoxification of cassava during fermentation with a mixed culture innoculum. Journal Science of Food and Agriculture 63: 473-481.

69. Ampe F. \& Brauman A. (1995). Origin of enzymes involved in detoxification \& root softening during cassava retting. World Journal of Microbiology and Biotechnology 11: 178-182.

70. Essers A.J.A., Bennik M.H.J. \& Nout M.J.R. (1995). Mechanism of increased linamarin degradation during solid substrate fermentation of cassava. World Journal Microbiology and Biotechnology 11: 266-270.

71. Cuzin N. \& Labat M. (1992). Reduction of cyanide levels during anaerobic degradation of cassava. International Journal of Food Science 27 : 329-336.

72. Nambisan B. \& Sundaresan S. (1985). Effect of processing on the cyanoglucoside content of cassava. Journal of Science of Food and Agriculture 36: 1197-1203.

73. Bora P.S., Marriath M.R. \& Fioreze R. (1992). Change in the moisture and cyanide contents of bitter cassava during artificial and solar drying. Development Technology 20 : 375-382.

74. Jones D.M. \& Trim D.S. (1994). Influence of selected process variables on the elimination of cyanide from cassava. Journal of Science of Food and Agriculture 66 : 535-542.

75. Gomez G. \& Valdiviero M. (1985). Effect of drying temperature and loading rates on cyanide elimination from cassava whole root chips. Journal of Food Technology 20 : 375-382.

76. Jansz E.R., Jeyaraj E.E., Pieris N.M. \& Abeyratne D.J. (1974). Cyanide liberation from linamarin. Journal of the National Science Council, Sri Lanka 2 : 57-65.

77. Bourdoux P., Mafuta M., Hanson A. \& Ermans A.M. (1980). Cassava toxicity: the role of linamarin. In: The role of cassava etiology of goitre and cretinism. see Reference No. 82. pp. 15-27.

78. Nicholls L. (1949). In : Tropical nutrition and dietetics. Bailliere, London.

79. Gibb M.C., Carbery J.T., Carter R.G. \& Catàllinac S. (1974). Hydrocyanic acid poisoning of cattle associated with sudax grass. New Zealand Veterinary Journal 22 : 127. 
80. Jansz E.R. (1990). Unpublished results, CISIR report.

81. Nestel B. \& Macintyre R. (1973). Chronic cassava toxicity. Proceedings of an interdisciplinary workshop. London, 29-30 January 1973. IDRC Oloe pp. 11-162.

82. Ermans A.M., Mbulamoko N.M., Delange F.\& Ahluwalia R. (1980). Role of cassava in the etiology of endemic goitre and cretinism. IDRC - $136 \mathrm{e}$. pp 13160.

83. Delange F. \& Ahluwalia R. (1982). Cassava toxicity and thyroid : research and public health issues. Proceedings of a workshop held in Ottawa, Canada, 31 May - 2 June 1982. IDRC - 207e. pp 7-146.

84. Ekpechi O.L. (1973). Endemic goitre and high cassava diets in Eastern Nigeria. See reference No. 82 pp. 139-145.

85. Lagasse R., Luvivila K., Yunga Y.M., Gerard M., Hanson A., Bourdoux P., Delange F. \& Thilly C.H. (1980). Endemic goitre and cretinism in Ubangi. See reference No. 82. pp 45-60.

86. Osuntokun B.O. (1973). Ataxic neuropathy associated with high cassava diets in West Africa. See reference No. 81. pp. 127-138.

87. Wilson J. (1973). Cyanide and human disease. See reference 81. pp 121- 125.

88. Geevargheese P.J. (1982). Cassava diet, tropocal calcifying pancreatitis and pancreatic diabetes. See reference No. 81. pp 77-78.

89. Banea M. (1993). Cassava processing, dietary cyanide exposure and Konzo in Zaire. Master of Medical Science Thesis, Uppsala University.

90. Lang K. (1933). Die Rhodanbildung in Tierkorpur. Biochem. Z. 259 : 243256. (From Reference No. 82).

91. Nambisan B. \& Sundaresan S. (1994). Distribution of linamarin and its metabolizing enzymes in cassava tissue. Journal of Science of Food and Agriculture 66 : 503-507.

92. Wood J.L. \& Cooley S.L. (1956). Detoxification of cyanide by cystine. Journal of Biological Chemistry 218 : 449-457.

93. Meister A. (1953). Preparation and enzymic reaction of the keto analozines of asparagine and glutamine. Fed. Proceedings 12: 245. (From reference No. 83). 
94. Meister A., Fraser P.E. \& Tice S.V. (1954). Enzymatic desulfuration of $\beta$-mercaptopyruvate to pyruvate. Journal of Biological Chemistry 206 : 561-575.

95. Oke O.L. (1973). The mode of cyanide detoxification. See reference no. 81 . pp. 97-104.

96. Goldstein F., Rieders F. (1953). Conversion of thiocyanate to cyanide by erythrocytic enzyme. American Journal of Physiology 173 : 287-290.

97. Amarasinghe T.D.C.M.D. (1981). A radio-tracer study on the catabolism of linamarin. M.Phil Thesis, University of Colombo.

98. Barrett M.D.P. (1976). Dietary cyanide, linamarin and nutritional deficiencies. Ph.D. Thesis, University of Guelph.

99. Hernandez T.M., Lundquist P. \& Oliveira L. (1995). Fate in humans of dietary intake of cyanogenic glucosides from roots of sweet cassava consumed in Cuba. Natural Toxins 2: 114-117.

100. Umoh T.B., Ognnkoyo F.O., Maduagwa E. \& Oke O.C. (1995). Effects of thiamin status on the metabolism of linamarin in rats. Annals of Nutritional Metabolism 29 : 319-324.

101. Collier J.L. (1988). Possible adaptation to serum thiocyanate overload associated with chronic sublethal dietary cyanide ingestion. Human Biology 60: 615-622.

102. Ononogbu I., Echeta C. \& Nwabuene B.C. (1987). Haemoglobin glycosylation and erythrocyte free fatty acid concentration in gari - fed rats. Nutrition Research (N.Y.) 7: 883-886.

103. Padmaja G.M., Pannikkar K.R. (1989). Intermediary metabolic changes in rabbits administered linamarin or KCN. Indian Journal of Experimental Biology 27: 635-639.

104. Collier J.L. (1988). Behavioural effect of chronic sublethal dietary cyanide in an animal model; implication for humans consuming cassava (Manihot esculenta). Human Biology 60 : 597-614.

105. Perera W.D.A., Jayasekera P.M. \& Thaha, S.Z. (1989). Tables of food composition as used in Sri Lanka. Medical Research Institute, Sri Lanka (UNICEF Publication) p. 3. 
106. Ravindran V. (1993). Utilization of Manihot esculenta leaves in animal nutrition. Journal of the National Science Council, Sri Lanka 21: 1-26.

107. Jansz E.R. \& Karunatilleke N. (1992). Unpublished results, CISIR reports.

108. Chonchol N. \& Tovar J. (1988). Dietary fibre content and starch digestibillity in cassava bread. Nutritional Reports 38 : 437-443.

109. Morales E. \& Grahan G.G. 1987). Digestibility of boiled and oven-dried cassava in infants and small children. Journal of Nutrition 117:129-132.

110. Kurup P.G. \& Krishanamuthy S. (1992). Glycaemic index of selected foodstuffs commonly used in South India. International Journal of Vitamin and Nutrition Research 62 : 266-268.

111. Brough S.H. \& Neale R.J. (1990). Characterization of the dietary fibres of cassava. Special Publication of the Royal Society of Chemistry 83: 133-135.

112. Moorthy S.N., Jos. J.S., Nair R.B., Sreekumari M.T. (1990). Variability of $\beta$-carotene content in cassava germplasm. Food Chemistry 36 : 233-236.

113. Flores C.I.O. \& Penteado M. De V.C. (1992). Carotenoids with provitamin A activity in several cassava cultivars (Manihot esculenta Crantz) from Sao Paulo state. Review Farm Bioquim. Uni. 28 : 51-60. 